Brit. J. vener. Dis. (1961), 37, 130.

\title{
EPIDEMIOLOGICAL ASPECTS OF GONORRHOEA IN OPORTO, PORTUGAL*
}

\author{
BY \\ MARIO CARDIA \\ Director of the Social Hygiene Dispensary of Oporto \\ AND \\ AURELIANO DA FONSECA \\ Chief of the Dermatology Service at the same Dispensary
}

Our knowledge of endemic venereal disease in Oporto $\dagger$ is principally derived from the records of the Dermatological and Gynaecological Services of the Social Hygiene Dispensary, for the following reasons:

(a) Most of the dermatological and gynaecological consultations in the city take place there;

(b) The consultations, laboratory analyses, and drugs are free to all, whatever the economic or social status of the patient;

(c) No documents are required for the consultations;

(d) During the clinical examinations, an effort is made to detect venereal disease;

(e) There is an organized social service for contact tracing and for following up patients during treatment until the disease has been cured.

The dispensary, reorganized in 1947, registers an average of 8,000 new cases yearly $\ddagger$, nearly 3,000 male and about 5,000 female patients.

During the 10 years from 1949 to $1959,86,163$ patients were registered $(34,072$ men and 52,090 women), among whom 9,798 cases of gonorrhoea were diagnosed (9,454 male and 344 female).

The ratio of cases of gonorrhoea to the total number of cases of venereal disease in both sexes

* Presented at the European Symposium of the I.U.V.D.T. at Cracow, Poland, in September, 1960.

† The city of Oporto has nearly 300,000 inhabitants; it is the capital of a small district with $1,300,000$ inhabitants. It is an important industrial and commercial centre with both a sea port and a river port.

¥ This figure refers only to the dermatological and gynaecological services, for the dispensary is a polyvalent organization and is also provided with services for eye diseases and stomatology. shows unequal fluctuations (Table). For males, the average ratio was 27.9 per cent. (range 15.5 to 41.6 per cent.). For females, the average ratio was 0.6 per cent. (range 0.1 to 1.8 per cent.). For both sexes as a whole the ratio was 10.5 per cent. (range 6.3 to $16 \cdot 1$ per cent.).

The annual figures show that the incidence of gonorrhoea remains at a steady high level, particularly for males.

The foci of infection are persistent and are escaping prophylactic action, despite all our efforts. These figures must not be regarded as a proof that the disease is relatively rare among women, since its clinical characteristics in women are such that they often go unnoticed and persist in a latent state. Furthermore, because the public know how easily venereal diseases can be cured men have ceased to use condoms as a prophylactic measure, and employ them, if at all, for birth control. We know that at the other clinics where venereal diseases are treated, gonorrhoea is seen with the same frequency.

All physicians, particularly those of the gynaecological services, should therefore endeavour to

TABLE

PERCENTAGE OF CASES OF GONORRHOEA RELATED TO THE TOTAL NUMBER OF PATIENTS TREATED, 1950-1959

\begin{tabular}{|c|c|c|c|}
\hline \multirow{2}{*}{ Year } & \multicolumn{2}{|c|}{ Sex } & \multirow{2}{*}{ Total } \\
\hline & Male & Female & \\
\hline $\begin{array}{l}1950 \\
1951 \\
1952 \\
1953 \\
1954 \\
1955 \\
1956 \\
1957 \\
1958 \\
1959\end{array}$ & $\begin{array}{l}29.9 \\
36.8 \\
26.2 \\
25.8 \\
40.4 \\
35.4 \\
41.6 \\
17.5 \\
15.5 \\
25.4\end{array}$ & $\begin{array}{l}1.8 \\
0.4 \\
0.3 \\
0.8 \\
1.1 \\
0.6 \\
0.8 \\
0.1 \\
0.4 \\
0.5\end{array}$ & $\begin{array}{r}12 \cdot 9 \\
16 \cdot 1 \\
11 \cdot 1 \\
10 \cdot 2 \\
10 \cdot 2 \\
14 \cdot 3 \\
15 \cdot 5 \\
7 \cdot 4 \\
6 \cdot 3 \\
10 \cdot 2\end{array}$ \\
\hline
\end{tabular}


detect latent gonorrhoea by carrying out careful clinical examinations, supplemented in all cases by lảboratory tests based on cultures.

\section{Aspects epidémiologiques de la blennorragie dans la ville de Porto (Portugal) \\ Résumé}

En examinant les fréquences annuelles, on constate que la blennorragie se maintient à un taux épidémiologique élevé, surtout pour le sexe masculin, et qu'elle présente un caractère plus ou moins stable.

Cela signifie que les foyers infectieux de la maladie se maintiennent, échappant à l'action prophylactique, malgré tous nos efforts.
La rareté apparente de la maladie chez les femmes n'indique par l'indice épidémiologique, car les caractéristiques cliniques, n'éveillant généralement pas l'attention des malades, favorisent son maintien à l'état latent chez les femmes.

D'un autre côté, les facilités de guérison des maladies vénériennes étant connues du public, l'homme a cessé d'employer les condoms comme moyen prophylactique, c'est à peine s'il s'en sert comme moyen anticonceptionnel.

Nous savons que, dans les autres cliniques où se traitent habituellement des maladies vénériennes, la blennorragie se présente avec une fréquence identique.

Tous les médecins, surtout ceux des services de gynécologie, doivent donc chercher à dépister la blennorragie latente par les examens cliniques détaillés, toujours complétés par des examens au moyen de cultures. 